\title{
THE VISCOSITY OF SULPHURIC-ACID SOLUTIONS USED FOR BATTERY ELECTROLYTES
}

\author{
By G. W. Vinal and D. N. Craig
}

\begin{abstract}
The viscosity of sulphuric-acid solutions used for the elecrolyte in lead-acid storage batteries is a factor affecting the diffusion of the electrolyte through the porous material of the plates and separators. The decreased capacity of batteries at low temperatures is attributable in part to increase in viscosity of the electrolyte. Storage batteries are commonly used under widely different conditions of temperature, but data for the viscosity of the electrolyte at temperatuers below $0^{\circ} \mathrm{C}$. have not been previously available. The viscosity of sulphuric-acid solutions containing 10 to 50 per cent acid has now been measured over a temperature range from $+30^{\circ} \mathrm{C}$. to $-50^{\circ} \mathrm{C}$., the measurements for some solutions being limited, however, by their freezing points. Below $0^{\circ} \mathrm{C}$. the viscosity of the solutions increases rapidly as the temperature is diminished.
\end{abstract}

\section{CONTENTS}

I. Introduction

II. The apparatus

1. Description of apparatus

2. Calibration of the viscometer

III. Experimental results

IV. Discussion of the results

1. Accuracy of the measurements

2. Comparison with previous determinations

V. Summary

VI. Acknowledgements

\section{INTRODUCTION}

Storage batteries of the lead-acid type are now used under such widely differing conditions of temperature and rate of discharge that an extension of our knowledge of the basic properties of sulphuricacid solutions which are employed for the electrolyte is desirable. Resistivity and viscosity of the solutions are two of the more important properties of the electrolyte which affect the performance of batteries. The useful voltage of a battery is decreased as the resistivity of the electrolyte increases. The viscosity affects the rate of diffusion of the electrolyte through the porous material of the plates and separators. Increase in viscosity results in decreased capacity of a battery. Both resistivity and viscosity are, therefore, factors determining the amount of electrical energy which a battery can deliver under specified conditions of temperature and rate of discharge. As a part of a comprehensive investigation of the properties and behavior of battery electrolytes and separators the viscosity of sulphuric-acid 
solutions from 10 to 50 percent $\mathrm{H}_{2} \mathrm{SO}_{4}$ have been measured. The viscosity measurements have been made over a temperature range from $+30^{\circ} \mathrm{C}$. to $-50^{\circ} \mathrm{C}$. insofar as the temperatures were above the freezing points of the solutions. In the present paper the results of these viscosity measurements are given, and in a later paper we expect to give the results of our work on the resistance of battery separators and the resistivity of sulphuric-acid solutions.

Although several authors have published values for the viscosity of sulphuric-acid solutions at ordinary temperatures and above, data are not available in the literature for temperatures below $0^{\circ} \mathrm{C}$. Wagner ${ }^{1}$ measured the viscosity of dilute solutions, 1.0035 to 1.2003 specific gravity, at temperatures of $15^{\circ}$ to $45^{\circ} \mathrm{C}$. Dunstan and Wilson ${ }^{2}$ measured the viscosity of a large number of solutions ranging from dilute to concentrated acid at $25^{\circ} \mathrm{C}$.

Rhodes and Barbour ${ }^{3}$ also measured the viscosity of a large number of solutions ranging from dilute to concentrated acid. Their measurements were made at $0^{\circ}, 25^{\circ}, 50^{\circ}$, and $75^{\circ} \mathrm{C}$. Their paper is the only one, which we have found, giving viscosities at temperatures as low as $0^{\circ} \mathrm{C}$. In the same year Bingham and Stone ${ }^{4}$ published the results of their measurements on solutions from 11 to 97 percent acid at $10^{\circ}$, $20^{\circ}$, and $40^{\circ} \mathrm{C}$.

Grunert ${ }^{5}$ measured the viscosity of sulphuric-acid solutions from 0.4344 to 3.475 molar at temperatures of $20^{\circ}, 40^{\circ}, 60^{\circ}$, and $80^{\circ} \mathrm{C}$.

In a later section of this paper the values reported by the above authors are compared with the present determinations. Such a comparison, however, is necessarily limited to few values since our work extended to low temperatures while previous work was mostly confined to measurements at higher temperatures.

\section{THE APPARATUS}

\section{DESCRIPTION OF APPARATUS}

The viscosity measurements were made by timing the discharge of a fixed volume of solution through the capillary tube of a viscometer made of Pyrex glass. The ratio of the length of the capillary to its diameter was approximately 100 . A diagram of the apparatus which was employed is shown in figure 1. The liquid was drawn up in the viscometer above index $A$ and then released. The passage of the miniscus from $\mathrm{A}$ to $\mathrm{B}$ was timed.

The viscometer and the tube surrounding it, containing one of the sulphuric-acid solutions, or a liquid used for calibrating the instrument, were placed in a temperature-controlled bath in a Dewar flask of clear glass. This was provided with a stirrer. For measurements at $20^{\circ} \mathrm{C}$. and above, the temperature was regulated and held constant by the addition of small portions of warm or cold water to the water in the Dewar flask. At temperatures below $20^{\circ} \mathrm{C}$. the water in the Dewar flask was replaced by alcohol and the temperature was adjusted and held constant during each experiment by adding small portions of solid carbon dioxide.

\footnotetext{
1 Ann.dPhys., vol. 254, p. 259, 1883, and Zeit.Phys.Chem., vol. 5, p. 31, 1890.

Chem. Soc. vol. vo, p. 104, 1914.

Ind. and Eng. Chem., vol. 15, p. 850, 1923.

J.Phys. Chem., vol. 27, p. 701, 1923.

Z Zeit. A norg. Chem., vol. 145, p. 394, 1925.
} 
Reference lines etched on the viscometer and on the tube surrounding it served to fix the position of the viscometer relative to the tube. The level of liquid in the tube was adjusted for each experiment to an etched line on the tube ( $C$ in the diagram) before drawing the liquid up into the viscometer. Slight adjustments in level of the liquid were accomplished by raising or lowering the thermometer to

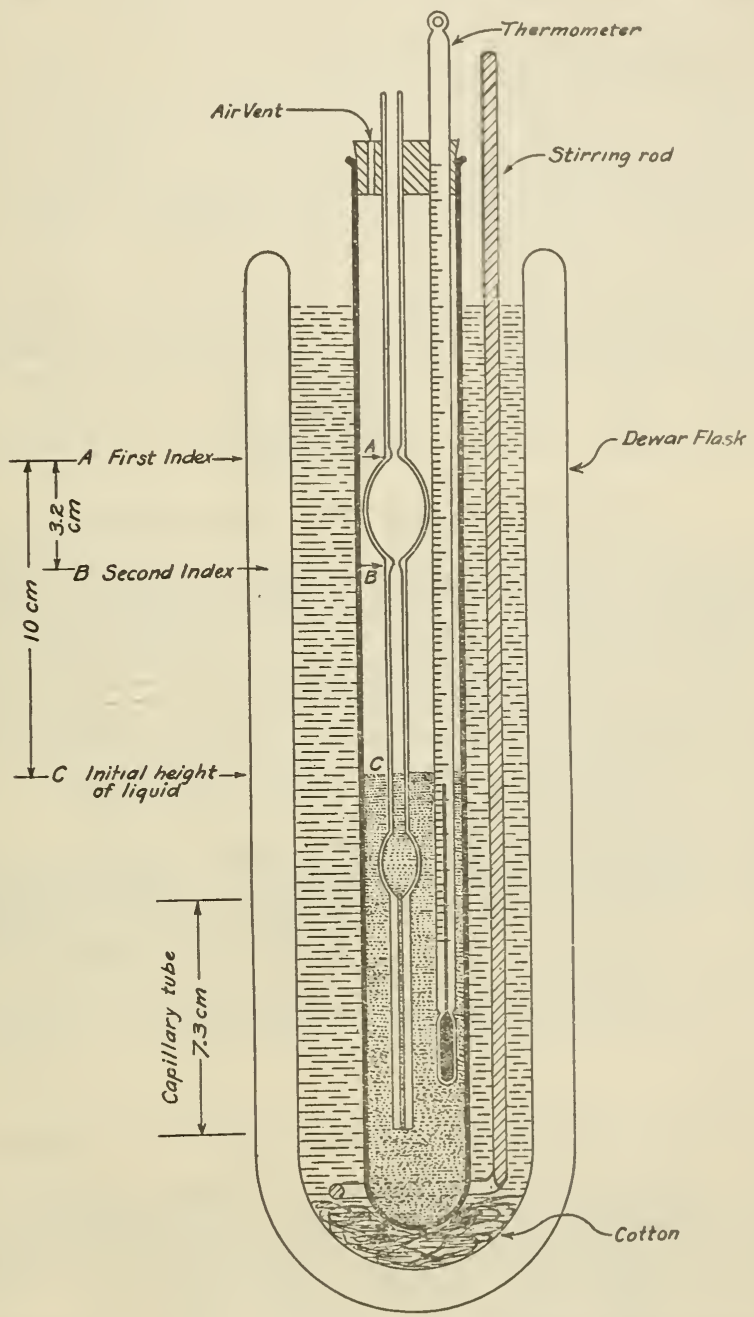

FIGURE 1.-Viscometer and temperature-controlled bath.

compensate for the expansion or contraction of the liquid as the temperature was changed. The same head of the liquid was thereby obtained at the beginning of each discharge. The viscometer was provided with two bulbs, the lower bulb always being immersed in the liquid. This aided materially in equalizing temperatures before the liquid passed through the capillary tube. 
The temperature was read on a thermometer which was placed directly in the solutions to be measured and adjacent to the capillary of the viscometer. The thermometer employed for temperatures above $-1^{\circ} \mathrm{C}$. was a mercury-in-glass type graduated in tenth degrees, and estimations were made to $0.01^{\circ} \mathrm{C}$. Below $-1^{\circ} \mathrm{C}$. and above $-20^{\circ}$ C. a mercury-in-glass thermometer was also used. This was graduated in degrees, estimations being made to $0.1^{\circ} \mathrm{C}$. Below $-20^{\circ}$ C. a toluene-in-glass thermometer was used. This was also graduated in degrees and estimations were made to $0.1^{\circ} \mathrm{C}$. All of these thermometers had been calibrated previously and corrections were applied to the readings. As a further check of the readings of the toluene thermometer, the viscometer was replaced by a platinum resistance thermometer and it was found that the conditions of the experiment afforded sufficient opportunity for drainage in the toluene thermometer.

The temperature of the solutions was observed frequently during each measurement and the average temperature calculated. Some determinations were made so quickly that the temperature was observed only at the beginning and end of the discharge. In determinations of longer duration, the temperature was observed 6 or 8 times.

\section{CALIBRATION OF THE VISCOMETER}

The viscometer was calibrated by measuring the time of discharge of liquids of known viscosity. These included distilled water, sucrose solutions, ethyl-alcohol solutions, and two standardized oils. The sucrose solutions were prepared by weight from standard samples of sucrose. One solution containing 20 percent and two other solutions containing 40 percent of sucrose were employed. Four solutions of ethyl alcohol and water were used. These contained $39.2,46.4,49.7$, and 50.5 percent alcohol by weight.

The time of discharge for each liquid, except the oils, was measured at several temperatures, six determinations being made at each temperature. The oils were measured only at $25^{\circ} \mathrm{C}$., since the viscosity of these samples had been certified at this temperature.

The values of viscosity, $\mu$, for water, sucrose solutions, and alcohol solutions were taken from the International Critical Tables ${ }^{6}$ except that a correction to the value for 40 percent sucrose solution at $10^{\circ} \mathrm{C}$. was necessary. ${ }^{7}$

In computing the kinematic viscosities, $\frac{\mu}{\rho}$, for the purpose of calibrating the viscometer, the densities, $\rho$, of water and the solutions employed have been taken from the International Critical Tables and from Bureau of Standards Technologic Paper No. 100. The densities of the oils were determined experimentally at $25^{\circ} \mathrm{C}$.

The constants of the viscometer, $A$ and $B$, were evaluated graphically ${ }^{8}$ by plotting the computed ratios of kinematic viscosities to time of discharge $\left(\frac{\mu}{\rho t}\right)$ of the calibrating liquids as ordinates against $\frac{1}{t^{2}}$ $(t=$ measured time of discharge in seconds). The results of the calibration measurements are shown in figure 2. The value of $A$ (the inter-

Higgins, Collected Researches, National Physical Laboratory, vol. 11, p. 12, 1914. 
cept of the straight line on the $y$-axis) and the value of $B$ (the slope of the straight line) were found to be 0.02365 and 2.333 , respectively. Calibration of the viscometer was necessarily extended over a wide range because of the large variation in viscosity of sulphuric-acid solutions from $+30^{\circ}$ to $-50^{\circ} \mathrm{C}$. The ealibration curve, however, shows no evidence of turbulent flow within the range for which this viscometer was actually used.

With the exception of the alcohol solutions, the maximun deviation of any value of $\frac{\mu}{\rho t}$ from the calibration line as drawn (fig. 2 ) is less than 1 percent and 15 out of 16 points for sucrose solutions, water and the oils are within one half of 1 percent of corresponding points on the line. The values obtained with alcohol solutions are, with one exception, above the line. Six out of ten of the alcohol points lie within 1 percent of the line, but these determinations have been given less weight in drawing the line, because values for the viscosity of alcohol solutions appear to be known less accurately than the others.

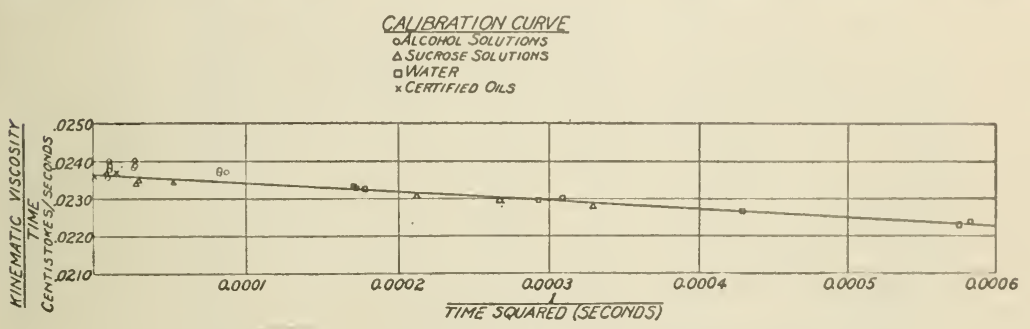

Figdre 2.-Calibration curve of the viscometer

\section{EXPERIMENTAL RESULTS}

The time of discharge of a specified volume of solution under test having been measured at a temperature $T^{\circ}$, the kinematic viscosity was calculated from the equation

$$
\left(\frac{\mu}{\rho}\right)_{T} \circ=A t-\frac{B}{t}
$$

in which $\left(\frac{\mu}{\rho}\right)$ is the kinematic viscosity, $t$ the time of flow in seconds and $A$ and $B$ are constants for the instrument which was used. The values of $A$ and $B$ were determined by the method described in a previous section. Eight different solutions of sulphuric acid ranging in composition from 10.1 to 49.1 percent by weight of $\mathrm{H}_{2} \mathrm{SO}_{4}$ were measured at temperatures between $-50^{\circ}$ and $+25^{\circ} \mathrm{C}$. $\left(-58^{\circ}\right.$ and $+77^{\circ}$ F.). These solutions were prepared from "Cp" acid and distilled water. They did not contain lead sulphate which is normally present in small amounts in battery electrolytes.

The composition of these solutions, expressed as percent $\mathrm{H}_{2} \mathrm{SO}_{4}$. was determined by titrating two weighed portions of each solution, 
Tho pereentanges so olntainod were 10.13, 14.68, 21.41, 28.13, 33.89, $40.17,45.45$, and 49.1. $\Lambda$ s a check on these doterminations the

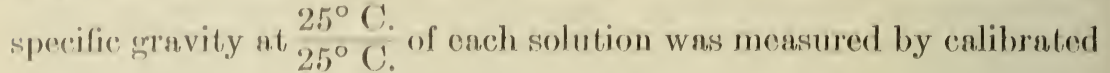
hydrometers which could be read to 0.0005 . The densities at $25^{\circ} \mathrm{C}$. were then calculated and converted to percentages by using data in tho Intermational Critical Tables. The averago difference between the measurements by titmtion and specific gravity was less than 0.1

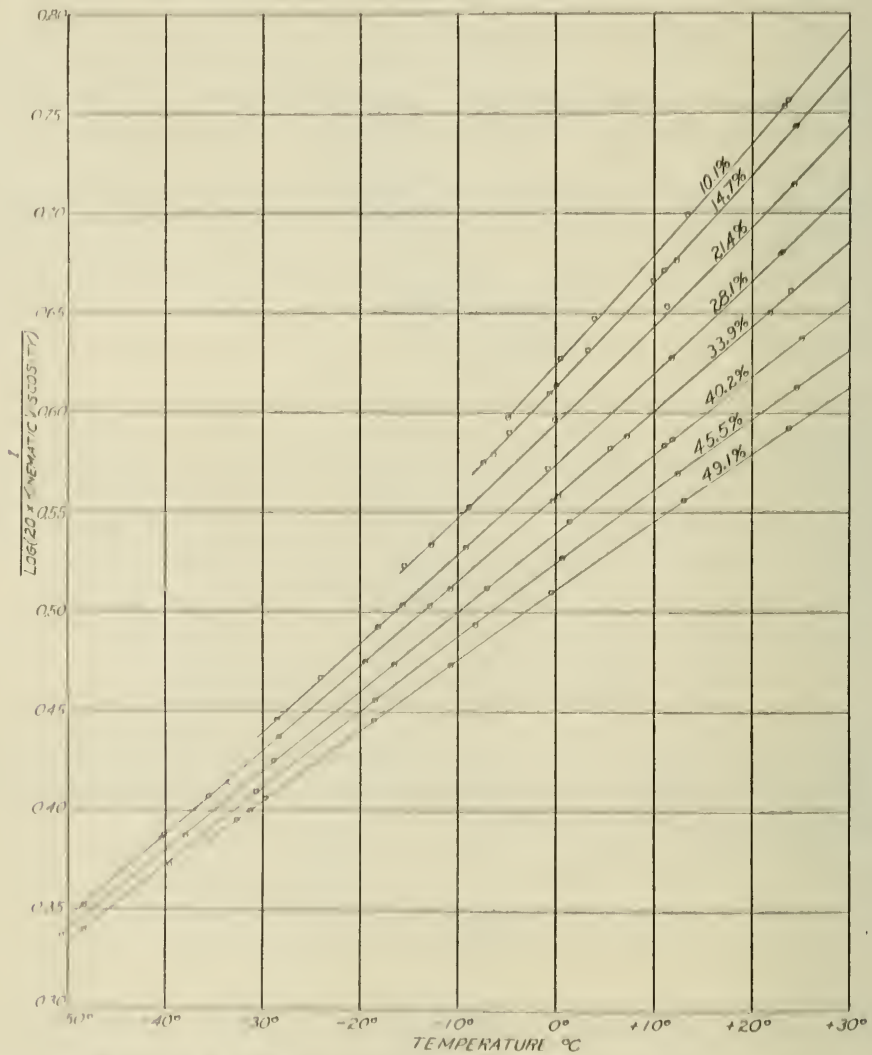

FıUи: 3.- Plot of the experimental determinations.

perent. The results griven in this paper are hased upon the values determined by titmotion.

Tho experimental resulis nre shown in figure 3. In plotting these curves we have followed a surgrestion, made by C. S. Crngoe, of this Burenu, that the reciprocal of $\log (20 \times$ kincmutic viscosity in centistokes) be plotted ngainst tempernture. Mr. Cragroo had found previonsly in the ense of oils that an approximately linear relntionship exists botwren this function nnd the temperature. 'Tho present work indicates that a similar relationship may exist for dectrolytes.

The individual points shown in figure 3 are, for tho most part, avernge results of 6 or 8 independent determinations. Somo experi- 


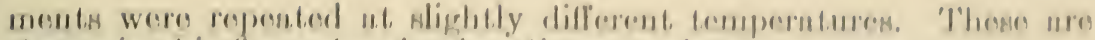

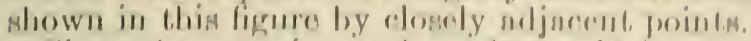

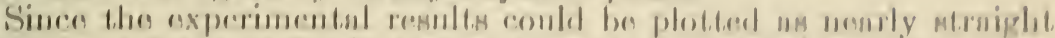

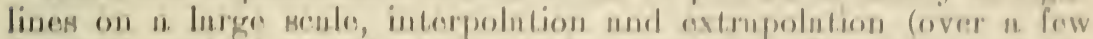

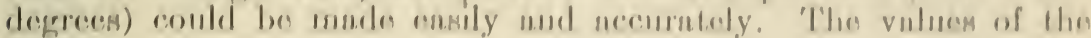
funcetion

Iogr (20) Klimemutice visconily)

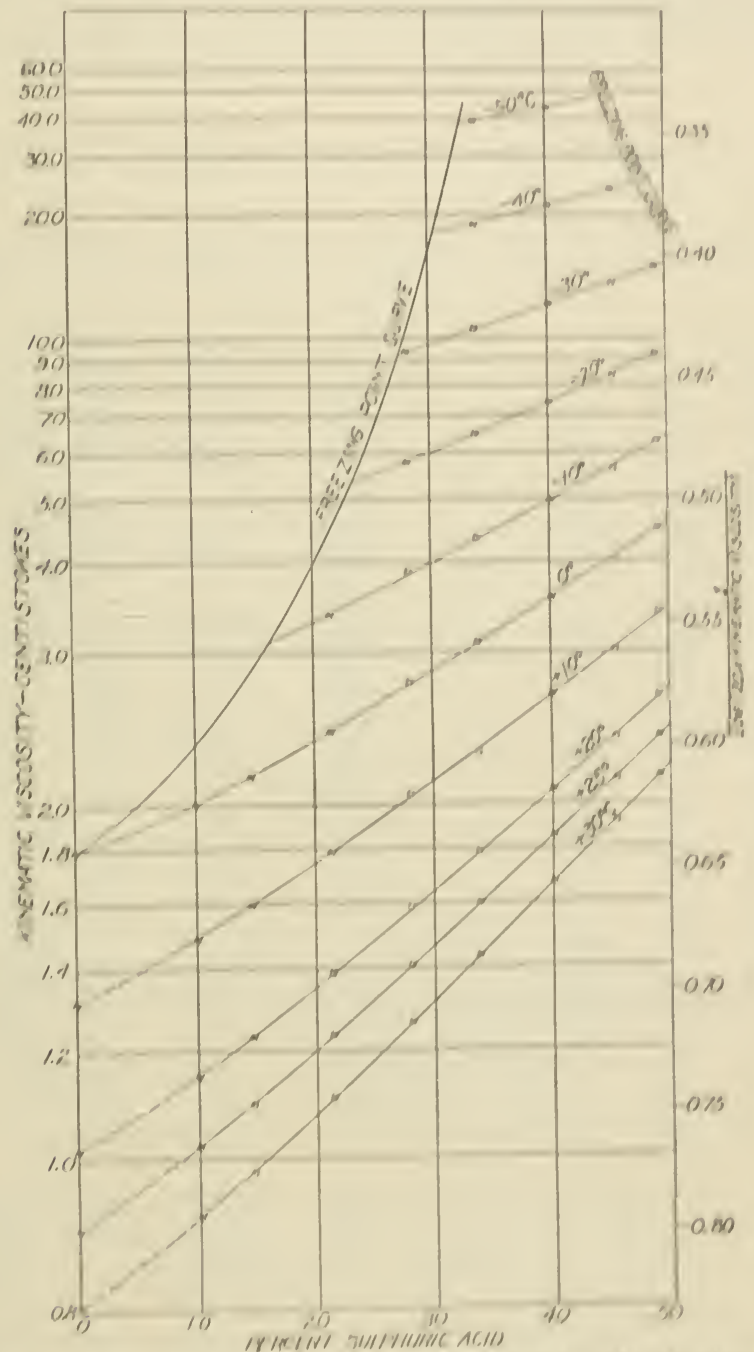

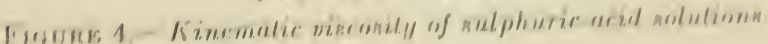

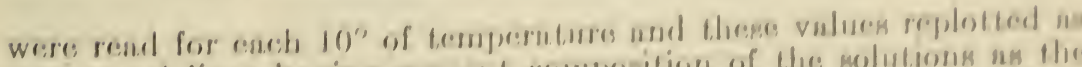

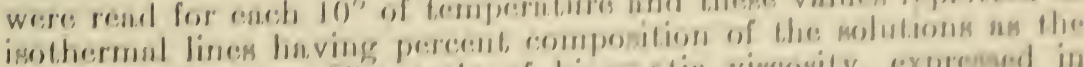

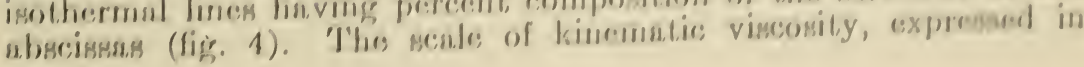


centistokes at the left of the diagram, has been calculated to correspond with the scale at the right. The figure shows two branches of the freezing point curve which limit the isothermals at the lower temperatures. Values for water taken from the International Critical Tables are plotted at 0 percent in this figure.

In order to compute the viscosity of these solutions from the kinematic viscosity it is necessary to know the density of each solution at each temperature. We have employed existing data as given in the International Critical Tables for temperatures above $0^{\circ} \mathrm{C}$. as a basis

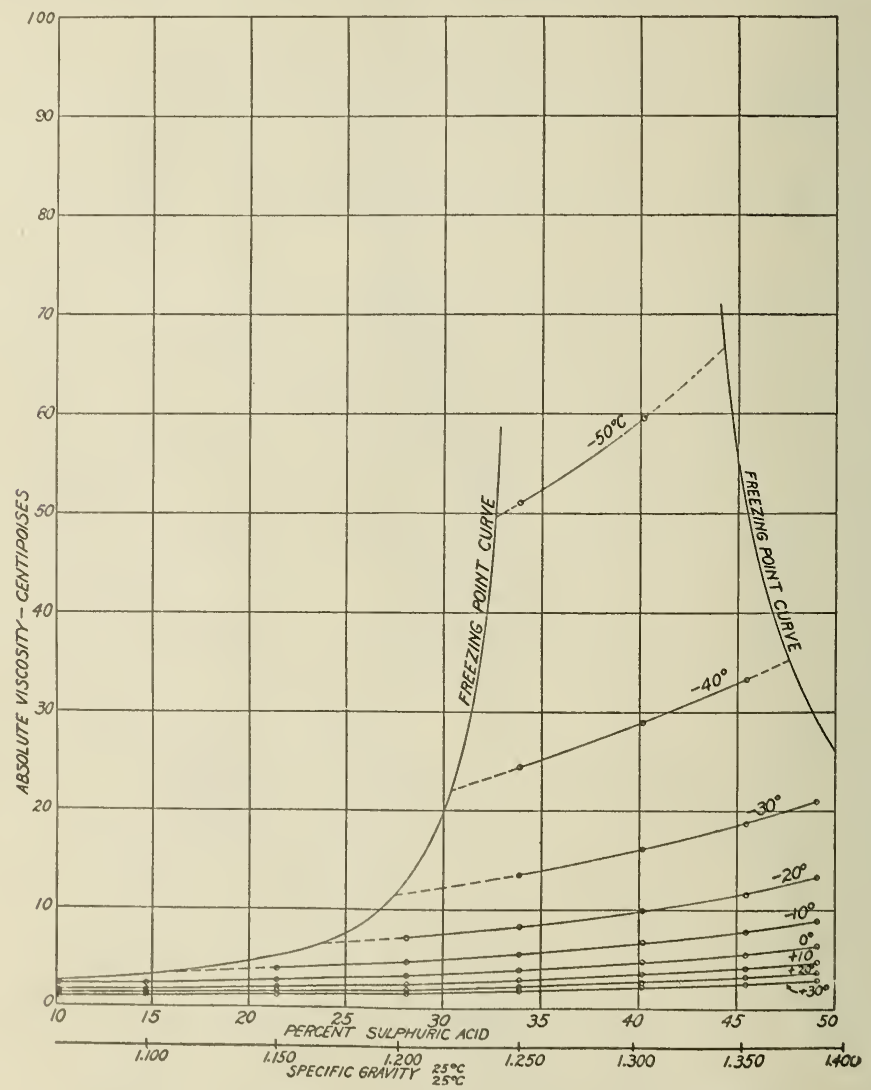

FIGURE 5.-Absolute viscosity of sulphuric-acid solutions.

for computing densities required at the various concentrations and temperatures. Below $0^{\circ} \mathrm{C}$. no such data appears to be available.

Since the variation of density with temperature is linear above $0^{\circ} \mathrm{C}$., we have calculated the densities below $0^{\circ} \mathrm{C}$. by extrapolation. In order to check the values below $0^{\circ} \mathrm{C}$. we have measured the contraction in volume of one solution as the temperature was decreased and found that the linear relation proved to be true. A pycnometer of Pyrex glass with graduated stem was used for this purpose. On the basis of the density of this solution at $0^{\circ} \mathrm{C}$., as given by the International Critical Tables and the observed contraction in volume, the density of this solution at $-50^{\circ} \mathrm{C}$. was calculated to be 1.3550 and the 
extrapolated value was 1.3548 . The difference between these values is negligible in calculating the absolute viscosities.

The viscosity expressed in centipoises is given in figure 5. 'To this figure has been added a scale of specific gravities at $25^{\circ} \mathrm{C}$. corresponding to the scale of percentages, in order to indicate more clearly the range of solutions which are customarily used in storage batteries.

Table 1 gives the numerical values for the kinematic viscosity, the absolute viscosity, and the fluidity (reciprocal of absolute viscosity) for sulphuric-acid solutions. In this table the viscosities are given to four significant figures for values less than 2.500, which are above $0^{\circ} \mathrm{C}$. The remainder of the table is uniformly given to three significant figures.

TABLE 1.-Viscosity and fluidity of solutions of sulphuric acid

\begin{tabular}{|c|c|c|c|c|c|c|c|c|c|}
\hline $\begin{array}{l}\text { Tempera- } \\
\text { ture }\left({ }^{\circ} \mathrm{C} .\right)\end{array}$ & $\begin{array}{c}\text { Percent } \\
\mathrm{H}_{2} \mathrm{SO}_{4}\end{array}$ & $\begin{array}{c}\text { Kine- } \\
\text { matic } \\
\text { viscosity }\end{array}$ & $\begin{array}{l}\text { Absolute } \\
\text { viscosity }\end{array}$ & Fluidity & $\begin{array}{l}\text { Tempera- } \\
\text { ture }\left({ }^{\circ} \mathrm{C} .\right)\end{array}$ & $\begin{array}{c}\text { Percent } \\
\mathrm{H}_{2} \mathrm{SO}_{4}\end{array}$ & $\begin{array}{l}\text { Kine- } \\
\text { matic } \\
\text { viscosity }\end{array}$ & $\begin{array}{l}\text { A bsolute } \\
\text { viscosity }\end{array}$ & Fluidity \\
\hline \multirow[t]{2}{*}{$30 \ldots$} & $\begin{array}{l}10 \\
15 \\
20 \\
25 \\
30\end{array}$ & $\begin{array}{l}\text { Centi- } \\
\text { stokes } \\
0.919 \\
.992 \\
1.081 \\
1.188 \\
1.318\end{array}$ & $\begin{array}{c}\text { Centi- } \\
\text { poises } \\
0.976 \\
1.088 \\
1.225 \\
1.392 \\
1.596\end{array}$ & $\begin{array}{r}1.026 \\
.919 \\
.816 \\
.718 \\
.626\end{array}$ & \multirow[t]{2}{*}{$0 \ldots$} & $\begin{array}{l}10 \\
15 \\
20 \\
25 \\
30\end{array}$ & $\begin{array}{l}\text { Centi- } \\
\text { stokes } \\
2.01 \\
2.16 \\
2.35 \\
2.58 \\
2.85\end{array}$ & $\begin{array}{l}\text { Centi- } \\
\text { pnises } \\
2.16 \\
2.41 \\
2.71 \\
3.08 \\
3.52\end{array}$ & $\begin{array}{r}0.464 \\
.416 \\
.369 \\
.325 \\
.284\end{array}$ \\
\hline & $\begin{array}{l}35 \\
40 \\
45 \\
50\end{array}$ & $\begin{array}{l}1.477 \\
1.670 \\
1.909 \\
2.214\end{array}$ & $\begin{array}{l}1.850 \\
2.163 \\
2.56 \\
3.07\end{array}$ & $\begin{array}{l}.541 \\
.462 \\
.391 \\
.326\end{array}$ & & $\begin{array}{l}35 \\
40 \\
45 \\
50\end{array}$ & $\begin{array}{l}3.17 \\
3.56 \\
4.03 \\
4.62\end{array}$ & $\begin{array}{l}4.04 \\
4.70 \\
5.49 \\
6.52\end{array}$ & $\begin{array}{l}.247 \\
.213 \\
.182 \\
.153\end{array}$ \\
\hline \multirow[t]{3}{*}{$25 \ldots$} & $\begin{array}{l}10 \\
15 \\
20 \\
25 \\
30\end{array}$ & $\begin{array}{l}1.026 \\
1.108 \\
1.207 \\
1.327 \\
1.468\end{array}$ & $\begin{array}{l}1.091 \\
1.218 \\
1.371 \\
1.559 \\
1.784\end{array}$ & $\begin{array}{l}.917 \\
.821 \\
.729 \\
.641 \\
.561\end{array}$ & \multirow[t]{2}{*}{-10} & $\begin{array}{l}20 \\
25 \\
30 \\
35\end{array}$ & $\begin{array}{l}3.30 \\
3.62 \\
4.00 \\
4.45\end{array}$ & $\begin{array}{l}3.82 \\
4.33 \\
4.95 \\
5.70\end{array}$ & $\begin{array}{l}.262 \\
.231 \\
.202 \\
.175\end{array}$ \\
\hline & $\begin{array}{l}35 \\
40\end{array}$ & $\begin{array}{l}1.645 \\
1.854\end{array}$ & $\begin{array}{l}2.067 \\
2.409\end{array}$ & $\begin{array}{l}.484 \\
.415\end{array}$ & & $\begin{array}{l}40 \\
45 \\
50\end{array}$ & $\begin{array}{l}4.98 \\
5.64 \\
6.45\end{array}$ & $\begin{array}{l}6.60 \\
7.72 \\
9.15\end{array}$ & $\begin{array}{l}.152 \\
.129 \\
.109\end{array}$ \\
\hline & $\begin{array}{l}45 \\
50\end{array}$ & $\begin{array}{l}2.120 \\
2.447\end{array}$ & $\begin{array}{l}2.85 \\
3.40\end{array}$ & $\begin{array}{l}.351 \\
.294\end{array}$ & $-20 \ldots$ & 25 & $\begin{array}{l}5.50 \\
6.01\end{array}$ & $\begin{array}{l}6.63 \\
7.49\end{array}$ & $\begin{array}{r}.151 \\
133\end{array}$ \\
\hline \multirow[t]{2}{*}{$20 \ldots \ldots$} & $\begin{array}{l}10 \\
15 \\
20 \\
25 \\
30\end{array}$ & $\begin{array}{l}1.152 \\
1.245 \\
1.356 \\
1.490 \\
1.646\end{array}$ & $\begin{array}{l}1.228 \\
1.372 \\
1.545 \\
1.755 \\
2.006\end{array}$ & $\begin{array}{l}.814 \\
.729 \\
.647 \\
.570 \\
.499\end{array}$ & & $\begin{array}{l}35 \\
40 \\
45 \\
50\end{array}$ & $\begin{array}{l}6.64 \\
7.42 \\
8.36 \\
9.51\end{array}$ & $\begin{array}{r}8.56 \\
9.89 \\
11.5 \\
13.6\end{array}$ & $\begin{array}{l}.117 \\
.101 \\
.0868 \\
.0737\end{array}$ \\
\hline & $\begin{array}{l}35 \\
40 \\
45 \\
50\end{array}$ & $\begin{array}{l}1.841 \\
2.072 \\
2.368 \\
2.72\end{array}$ & $\begin{array}{l}2.319 \\
2.70 \\
3.19 \\
3.79\end{array}$ & $\begin{array}{l}.431 \\
.370 \\
.313 \\
.264\end{array}$ & $-30 \ldots$ & $\begin{array}{l}30 \\
35 \\
40 \\
45 \\
50\end{array}$ & $\begin{array}{c}9.73 \\
10.7 \\
11.9 \\
13.4 \\
15.1\end{array}$ & $\begin{array}{l}12.2 \\
13.9 \\
16.0 \\
18.6 \\
21.7\end{array}$ & $\begin{array}{l}.0520 \\
.0718 \\
.0626 \\
.0539 \\
.0460\end{array}$ \\
\hline \multirow[t]{2}{*}{$10 \ldots$} & $\begin{array}{l}10 \\
15 \\
20 \\
25 \\
30\end{array}$ & $\begin{array}{l}1.490 \\
1.612 \\
1.755 \\
1.919 \\
2.124\end{array}$ & $\begin{array}{l}1.595 \\
1.784 \\
2.010 \\
2.274 \\
2.60\end{array}$ & $\begin{array}{l}.627 \\
.561 \\
.498 \\
.440 \\
.384\end{array}$ & \multirow[t]{2}{*}{-40} & $\begin{array}{l}35 \\
40 \\
45\end{array}$ & $\begin{array}{l}19.4 \\
21.4 \\
23.7 \\
40.2 \\
43.9\end{array}$ & $\begin{array}{l}25.3 \\
28.8 \\
33.0 \\
52.6 \\
59.5\end{array}$ & $\begin{array}{l}.0395 \\
.0347 \\
.0303 \\
.0190 \\
.0164\end{array}$ \\
\hline & $\begin{array}{l}35 \\
40 \\
45 \\
50\end{array}$ & $\begin{array}{l}2.359 \\
2.66 \\
3.02 \\
3.47\end{array}$ & $\begin{array}{l}2.99 \\
3.48 \\
4.09 \\
4.86\end{array}$ & $\begin{array}{l}.335 \\
.287 \\
.245 \\
.206\end{array}$ & & & & & \\
\hline
\end{tabular}

In dealing with storage batteries it is convenient to employ the values for fluidity, since the capacity of the battery and the fluidity of the solution vary together and inverse relationships are thereby avoided. An analysis of the data in table 1 shows that the percentage change in fluidity of sulphuric-acid solutions with change in temperature is practically the same for a specified temperature interval, irrespective of the concentration of the acid. That is, if some tempera- 
ture, such as $25^{\circ} \mathrm{C}$., be chosen as standard and the fluidity of each solution at that temperature called 100 percent, the fluidity of each solution at other temperatures will increase or decrease in the same proportion. This is shown in table 2 . If the fluidity of any sulphuric-acid solution within the range covered by this paper is known at $25^{\circ} \mathrm{C}$., the approximate fluidity at any other temperature may be calculated. The application of this simple relation, which is the same for the sulphuric-acid solutions as for water, is probably limited to solutions whose so-called "specific viscosity" at various concentrations is a constant or nearly constant quantity with change in temperature. The term specific viscosity is applied to the ratio of the absolute viscosity of the solution to the absolute viscosity of water at the same temperature.

TABLE 2.-Percent change in fluidity with temperature

\begin{tabular}{|c|c|c|c|c|c|c|c|c|c|c|c|c|}
\hline \multirow[b]{2}{*}{$\begin{array}{l}\text { Temper- } \\
\text { ature } \\
\left({ }^{\circ} \mathrm{C} .\right)\end{array}$} & \multicolumn{2}{|c|}{ Water } & \multicolumn{2}{|c|}{$\begin{array}{c}10 \text { percent } \\
\mathrm{H}_{2} \mathrm{SO}_{4}\end{array}$} & \multicolumn{2}{|c|}{$\begin{array}{c}20 \text { percent } \\
\mathrm{H}_{2} \mathrm{SO}_{4}\end{array}$} & \multicolumn{2}{|c|}{$\begin{array}{c}30 \text { percent } \\
\mathrm{H}_{2} \mathrm{SO}_{4}\end{array}$} & \multicolumn{2}{|c|}{$\begin{array}{c}40 \text { percent } \\
\mathrm{H}_{2} \mathrm{SO}_{4}\end{array}$} & \multicolumn{2}{|c|}{$\begin{array}{c}50 \text { percent } \\
\mathrm{H}_{2} \mathrm{SO}_{4}\end{array}$} \\
\hline & $\begin{array}{l}\text { Flu- } \\
\text { idity }\end{array}$ & $\begin{array}{l}\text { Per- } \\
\text { cent } \\
\text { flu- } \\
\text { idity }\end{array}$ & $\begin{array}{l}\text { Flu- } \\
\text { idity }\end{array}$ & $\begin{array}{l}\text { Per- } \\
\text { cent } \\
\text { flu- } \\
\text { idity }\end{array}$ & $\begin{array}{l}\text { Flu- } \\
\text { idity }\end{array}$ & $\begin{array}{l}\text { Per- } \\
\text { cent } \\
\text { flu- } \\
\text { idity }\end{array}$ & $\begin{array}{l}\text { Flu- } \\
\text { idity }\end{array}$ & $\begin{array}{l}\text { Per- } \\
\text { cent } \\
\text { flu- } \\
\text { idity }\end{array}$ & $\begin{array}{l}\text { Flu- } \\
\text { idity }\end{array}$ & $\begin{array}{l}\text { Per- } \\
\text { cent } \\
\text { flu- } \\
\text { idity }\end{array}$ & $\begin{array}{l}\text { Flu- } \\
\text { idity }\end{array}$ & $\begin{array}{l}\text { Per- } \\
\text { cent } \\
\text { flu- } \\
\text { idity }\end{array}$ \\
\hline $\begin{array}{l}30 \\
25 \\
20 \\
10 \\
0\end{array}$ & $\begin{array}{r}1.248 \\
1.119 \\
.995 \\
.765 \\
.558\end{array}$ & $\begin{array}{r}112 \\
100 \\
89 \\
68 \\
50\end{array}$ & $\begin{array}{r}1.026 \\
.917 \\
.814 \\
.627 \\
.464\end{array}$ & $\begin{array}{r}112 \\
100 \\
89 \\
68 \\
51\end{array}$ & $\begin{array}{r}0.816 \\
.729 \\
.647 \\
.498 \\
.369\end{array}$ & $\begin{array}{r}112 \\
100 \\
89 \\
68 \\
51\end{array}$ & $\begin{array}{r}0.626 \\
.561 \\
.499 \\
.384 \\
.284\end{array}$ & $\begin{array}{r}112 \\
100 \\
89 \\
68 \\
51\end{array}$ & $\begin{array}{r}0.462 \\
.415 \\
.370 \\
.287 \\
.213\end{array}$ & $\begin{array}{r}111 \\
100 \\
89 \\
69 \\
51\end{array}$ & $\begin{array}{r}0.326 \\
.294 \\
.264 \\
.206 \\
.153\end{array}$ & $\begin{array}{r}111 \\
100 \\
90 \\
70 \\
52\end{array}$ \\
\hline $\begin{array}{l}-10 . . \\
-20 . . \\
-30 . . \\
-40 .- \\
-50 . .\end{array}$ & & & & & .262 & 36 & $\begin{array}{l}.202 \\
.133 \\
.082 \\
. \\
-.-\end{array}$ & $\begin{array}{r}36 \\
24 \\
15\end{array}$ & $\begin{array}{l}.152 \\
.101 \\
.062 \\
.035 \\
.017\end{array}$ & $\begin{array}{c}37 \\
24 \\
15 \\
8.4 \\
4.1\end{array}$ & $\begin{array}{l}.109 \\
.074 \\
.046 \\
\end{array}$ & $\begin{array}{l}37 \\
25 \\
16 \\
-. \\
--\end{array}$ \\
\hline
\end{tabular}

\section{DISCUSSION OF THE RESULTS}

\section{ACCURACY OF THE MEASUREMENTS}

The experimental determinations plotted in figure 3 are mostly averages of repeated measurements, in some cases as many as 6 or 8 repetitions having been made. The average deviation of any point from its curve as drawn in figure 3 does not exceed 0.4 percent above $-1^{\circ} \mathrm{C}$., or 0.5 percent below $-1^{\circ} \mathrm{C}$. The number of points exceeding a deviation of 1 percent from the curve is 4 for the temperatures above $-1^{\circ} \mathrm{C}$. and 6 below this temperature out of a total of 70 points. The drawing of curves for figure 4 from which the values given in table 1 have been calculated has reduced deviations to a smaller percentage.

The measurements are subject to systematic errors from several sources. We have endeavored to avoid systematic errors in calibrating the instrument by using a variety of solutions and oils for which the viscosity is known. Since the time of discharge of the oils at $25^{\circ} \mathrm{C}$. was equal to the longer periods required at the lowest temperatures for the sulphuric-acid solutions, drainage errors at the low temperatures are believed to be negligible. Referring to figure 2, it seems probable that any systematic errors in the constants of the instrument do not exceed 0.5 percent. The error caused by change in dimensions of the glass was calculated to be negligible. 
Systematic errors in determining the composition of the solution have been avoided as far as possible by checking the results of titrations by measurements of specific gravity. The final results given in this paper are based on the titrations alone, but the difference between the two methods of standardizing the solutions would not change the viscosities by as much as 0.3 percent.

Accidental errors in measuring the temperature of the solutions were minimized by repetitions of the discharges. At teriperatures above $-1^{\circ} \mathrm{C}$. the error in temperature of a single determination did not exceed $0.05^{\circ}$. This would correspond to 0.1 pereent error in the viscosity at $25^{\circ} \mathrm{C}$. Below $-1^{\circ} \mathrm{C}$. the viscosity increases rapidly with decreasing temperatures. At these temperatures the thermometer readings were estimated to tenth degrees and the average of 6 or 8 determinations were probably correct to $0.2^{\circ}$ which corresponds to 2 percent of the viscosity at $-40^{\circ} \mathrm{C}$. The crrors arising from the temperature measurements are therefore somewhat variable with the temperature, but are estimated to be 0.1 percent at $25^{\circ} \mathrm{C}$, 0.3 percent at $0^{\circ} \mathrm{C}$., and 2.0 percent at $-40^{\circ} \mathrm{C}$.

The errors in timing the discharges were minimized also by repetitions of the experiment. For a few of the fastest discharges the error in timing may have amounted to 0.5 percent. For most of the determinations, however, the error in timing probably did not exceed 0.2 percent and at the low temperatures 0.1 percent.

The last of the accidental sources of error to be mentioned is the adjustment of the head of the solution. The head was $10 \mathrm{~cm}$ so that an error of $0.5 \mathrm{~mm}$ would correspond to 0.5 percent in the viscosity measurement. The actual error from this source in the final results was probably not more than 0.2 percent.

In view of the estimated magnitude of the possible crrors given above, it is believed that the values above $-1^{\circ} \mathrm{C}$. are not in error by more than 1 percent. The values below $-1^{\circ} \mathrm{C}$. vary somewhat in accuracy according to the temperature, the uncertainty being from 1 to 3 percent. These statements are based, however, on the assumption that the viscosities for the liquids used in calibrating the viscometer, as given in the International Critical Tables, are sufficiently accurate for the purpose.

\section{COMPARISONS WITH PREVIOUS DETERMINATIONS}

Comparisons have been made with the results obtained by other's who have been mentioned in the introductory paragraphs. Since these earlier results cannot be calculated readily to the same percentages and temperatures, the comparison has been made graphically in figure 6 . The curves have been drawn through the points plotted for the present results as given in table 1 . The results of other workers have been plotted by distinctive characters. Excellent agreement between the results of Grunert, Wagner, Bingham, and Stone (except near 12 percent) and the results of the present investigation has beell found. In figure 6 we have plotted also the values for sulphuric-acid solutions selected for the International Critical 'Tables.?

Vol. 5, p. 12. 


\section{SUMMARY}

Measurements of the viscosity of sulphuric-acid solutions containing 10 to 50 percent acid have been made over a temperature range from $+30^{\circ}$ to $-50^{\circ} \mathrm{C}$., except as the measurements were limited by freezing points.

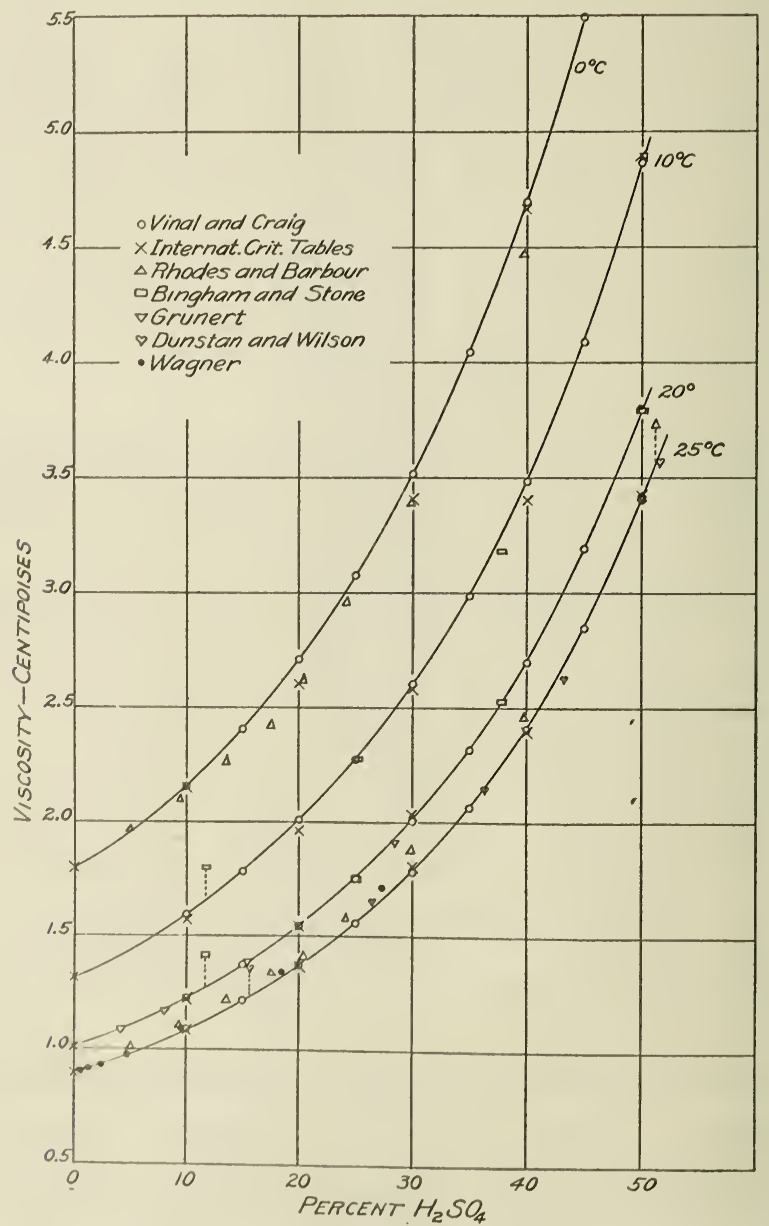

FIGURE 6.-Comparison of values for the viscosity of sulphuric-acid solutions.

The viscosity of these solutions at $0^{\circ} \mathrm{C}$. is about 2.2 times as great as at $+30^{\circ} \mathrm{C}$, , but at $-50^{\circ} \mathrm{C}$. the viscosity is 28 times as great.

Fluidities of the solutions have been calculated, since these are more simply related to changes in storage-battery capacity than the absolute viscosity.

The percentage change in fluidity of these solutions with temperature is very nearly the same irrespective of the percentage of acid contained in the solution. 


\section{ACKNOWLEDGMENTS}

The authors wish to thank C.S. Cragroe for permission to use his linear method of calculating the results in adrance of his own pulplication describing it. They are also indebted for hedpful advier fo Dr. N. E. Dorsey and W. H. Hersehel and R. C. Hardy, li. I. Pefter kindly calibrated the pyenomoter used for cheshimg the densities.

Wasmington, March 11, 1933. 